\title{
Impact of climate change on low-flows in the river Meuse
}

\author{
M. J. M. de Wit • B. van den Hurk • P. M. M. Warmerdam • \\ P. J. J. F. Torfs • E. Roulin • W. P. A. van Deursen
}

Received: 18 April 2005 / Accepted: 15 August 2006 / Published online: 27 January 2007

(C) Springer Science + Business Media B.V. 2007

\begin{abstract}
In this study observed precipitation, temperature, and discharge records from the Meuse basin for the period 1911-2003 are analysed. The primary aim is to establish which meteorological conditions generate (critical) low-flows of the Meuse. This is achieved by examining the relationships between observed seasonal precipitation and temperature anomalies, and low-flow indices. Secondly, the possible impact of climate change on the (joint) occurrence of these low-flow generating meteorological conditions is addressed. This is based on the outcomes of recently reported RCM climate simulations for Europe given a scenario with increased atmospheric greenhouse-gas concentrations. The observed record (1911-2003) hints at the importance of multi-seasonal droughts in the generation of critical low-flows of the river Meuse. The RCM simulations point to a future with wetter winters and drier summers in Northwest Europe. No increase in the likelihood of multiseasonal droughts is simulated. However, the RCM scenario runs produce multi-seasonal precipitation and temperature anomalies that are out of the range of the observed record for the period 1911-2003. The impact of climate change on low-flows has also been simulated
\end{abstract}

M. J. M. de Wit $(\bowtie)$

Rijkswaterstaat RIZA, Institute for Inland Water Management and Waste Water Treatment, Postbox 9072, 6800 ED Arnhem, The Netherlands e-mail: marcel.de.wit@rws.nl

B. van den Hurk

KNMI, Royal Netherlands Meteorological Institute,

De Bilt, The Netherlands

P. M. M. Warmerdam • P. J. J. F. Torfs

Department of Water Resources, Wageningen University,

Wageningen, The Netherlands

E. Roulin

KMI, Royal Meteorological Institute of Belgium,

Brussels, Belgium

W. P. A. van Deursen

Carthago Consultancy,

Rotterdam, The Netherlands 
with a hydrological model. This simulation indicates that climate change will lead to a decrease in the average discharge of the Meuse during the low-flow season. However, the model has difficulties to simulate critical low-flow conditions of the Meuse.

\section{Introduction}

Northwest Europe has a temperate climate, and rivers dominated by a rainfall-evaporation regime generally leading to low-flows in summer and high-flows in winter. The main rivers carry water throughout the year, a situation that has contributed to the region's prosperous development. The rivers are used for domestic, industrial and agricultural water supply, navigation, and also fulfil ecological and recreational functions. Floods and low-flows are natural phenomena that may hamper the above-mentioned functions of the rivers. Hence the benefits associated with using the rivers and their floodplains must be balanced against the risks inherent to their use. There is a growing concern that human-induced climate change may disturb the current balance. Should such a disturbance occur new strategies vis-à-vis water supply, navigation and spatial planning would be necessary.

The flow regimes of Northwest European rivers have been simulated in numerous studies under changing climate conditions; e.g., Sefton and Boorman (1996); Grabs et al. (1997); Gellens and Roulin (1998); Pilling and Jones (1999); Middelkoop et al. (2001); Shabalova et al. (2003); Booij (2005), and Kleinn et al. (2005). These studies have quantified changes in river runoff by comparing the output of hydrological models forced by observed climate records and climate data pertaining to future climate scenarios. The future climate scenarios are based on the output of General Circulation Models (GCMs), and more recently Regional Climate Models (RCMs). Due to the wide range of possible climate change scenarios in Northwest Europe, the range of possible changes in the flow regime of the region's rivers is also large. In general these studies suggest that humaninduced climate change will increase the risk of flooding in Northwest Europe, and may have a substantial impact on low-flows. However, the results for low-flows are not unequivocal and depend to a large extent on the type of climate change scenario used and the specific characteristics of the river basin.

It is predicted that a doubling of $\mathrm{CO}_{2}$ concentrations in the atmosphere will increase the average global temperature by between 1.5 and $4.5^{\circ} \mathrm{C}$ (IPCC 2001). Schär et al. (2004) argue that such a warming could lead to a pronounced increase in the occurrence of heat waves in Europe during the summer. The simulation of increased winter precipitation in northern Europe is quite robust across a set of different scenarios (Parry 2000). However, the simulated change of summer precipitation is less robust. Hydrological processes are dominated by complex interactions between land, atmosphere and circulation patterns (Seneviratne et al. 2002). Climate models tend to agree less on the signature of change in the summer precipitation regime in continental regions than on the signature of change in other seasons.

During dry spells the discharge of the Meuse is largely derived from the release of groundwater (de Wit et al. 2001). The basin's aquifers are mostly recharged during the winter. Hence, an increase of winter precipitation may reduce the occurrence of summer low-flows due to an increase in aquifer recharge. On the other hand, a decrease of summer precipitation and increased temperatures could potentially lead to an increase in the frequency of low-flows. This raises the question which meteorological conditions are the most important in the generation of (extreme) low-flows in the Meuse basin? 
In this paper this question is firstly addressed by analysing the relationships between observed seasonal precipitation and temperature anomalies, and low-flow indices. Ideally, the complex processes that determine the inputs to and outputs from low-flow discharge should be simulated with an integrated hydrological model. Several hydrological models have been successfully applied to (parts of) the Meuse basin: IRMB (Bultot and Dupriez 1976) by Gellens and Roulin (1998) or its distributed version SCHEME (Roulin and Vannitsem 2005), LISFLOOD (De Roo 2000), and HBV (Bergström and Forsman 1973) by Booij (2005) and Leander et al. (2005). The calibration and validation of these models focused on the similarity of observed and simulated discharges in terms of flow volumes, flood peaks and the overall shape of the hydrographs. No specific low-flow indices were used for calibration nor validation. In this study the results of a hydrological simulation of Meuse discharge using the HBV model are specifically validated against low-flow indices for the period 1968-1998.

This paper starts with a description of the Meuse basin (Section 2) and an overview of the data and models that were available for this study (Section 3). Section 4 presents the projected changes in precipitation and temperature for the Meuse basin as derived from recently reported RCM simulations for European climate under scenarios with increased atmospheric greenhouse-gas concentrations (PRUDENCE project). Section 5 includes a straightforward analysis of the relationships between observed seasonal precipitation and temperature anomalies, and low-flow indices for the period 1911-2003. Section 6 evaluates the performance of the HBV model in simulating low-flows in the Meuse basin in the period 1968-1998. The impact of climate change on low-flows in the Meuse basin is addressed both in Section 5 (Statistical analysis) and Section 6 (Hydrological simulation). The results are discussed and summarised in Sections 7 and 8.

\section{Meuse basin}

The Meuse basin covers an area of approximately $33,000 \mathrm{~km}^{2}$, including parts of France, Luxembourg, Belgium, Germany, and The Netherlands (see Fig. 1). The Meuse basin can be subdivided into three major geological zones. The first is the Lorraine Meuse (upstream of Charleville-Mézières). This part of the basin mainly consists of sedimentary Mesozoic rocks. The second zone is the Ardennes Meuse (between Charleville-Mézières and Liège). Here the river transects the Paleozoic rock of the Ardennes Massif. The third zone is located downstream of Liège. The Dutch and Flemish lowlands are formed by Cenozoic unconsolidated sedimentary rocks. About $60 \%$ of the Meuse basin is used for agricultural purposes (including pastures) and $30 \%$ is forested. The average annual precipitation ranges from 1,000 to $1,200 \mathrm{~mm}$ in the Ardennes to $700-800 \mathrm{~mm}$ in the Dutch and Flemish lowlands. The maximum altitude is just below $700 \mathrm{~m}$ above sea level. Snowmelt is not a major factor in the discharge regime of the Meuse. The average discharge of the Meuse at its outlet is approximately $350 \mathrm{~m}^{3} \mathrm{~s}^{-1}$. The average summer discharge of the Meuse is about one quarter of the average winter discharge. Mean precipitation displays little seasonal variation. The seasonal discharge variation reflects the variation in evapotranspiration.

The Meuse is used to supply water to about six million people in Belgium and The Netherlands. During the last decades the demand for water of good quality has increased with economic development and population growth. Moreover, there is a tendency in The Netherlands to exploit surface water instead of groundwater. The Meuse fulfils an important link in the network of canals and rivers that connect the harbours of Antwerp and Rotterdam to the European hinterland. At present about 30,000 cargo-boats navigate the 
river each year, and this number is expected to increase due to the stimulation of water transportation by national authorities. Given the existence of all of these functions of the Meuse, concerns surrounding the occurrence of critical low-flows are justified.

\section{Materials and methodology}

\subsection{Discharge data (1911-2003)}

The longest daily discharge record available for the Meuse dates back to 1911 and has been measured by Rijkswaterstaat at Borgharen (see Fig. 1) in The Netherlands. The area of the Meuse catchment upstream from Borgharen is approximately $21,000 \mathrm{~km}^{2}$. The Borgharen gauging station is located downstream of a stretch of river where a number of canals branch

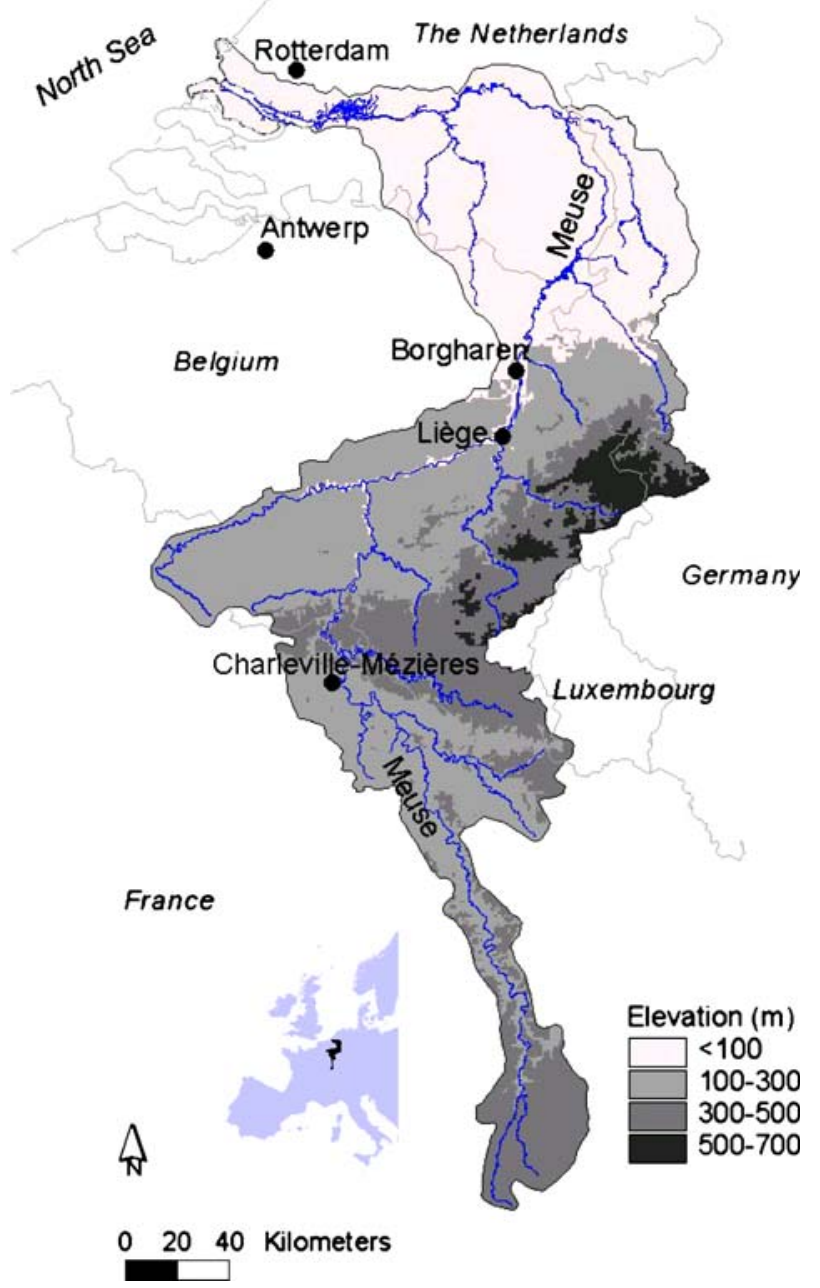

Fig. 1 Location of the Meuse basin 
off. The most important of these is the Albert Canal which runs from Liège to Antwerp (see Fig. 1). The distribution of water between the canals and the Meuse is regulated. The volumes of water extractions to the canals have changed over the past century and substantially affect the discharge at Borgharen, especially during low-flows. Bos (1993) designed a method to correct the Borgharen record for these extractions. The correction rates differ on a decadal time scale, but do not account for short term (e.g., daily) variations in water extractions. This method was applied to the Borgharen record, resulting in a 1911-2003 discharge record representing the 'undivided' Meuse. This corrected record

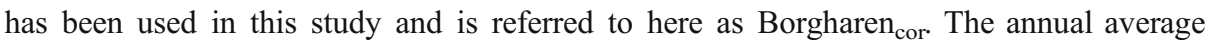
discharge of the 'undivided' Meuse is $270 \mathrm{~m}^{3} \mathrm{~s}^{-1}$. The discharge of the Meuse is influenced by the operation of weirs and reservoirs, which particularly affect discharge during lowflow events. Hence certain low-flow indicators, such as flow duration curves or the minimum daily or weekly average discharge, are not reliable for analysing low-flows in the Meuse.

\subsection{Low-flow indices}

Smakhtin (2001) gives an overview of low-flow indices and their estimation from streamflow time series. Although various low-flow indices describe different aspects of low-flow regime of a river, most of them are obviously strongly intercorrelated (Smakhtin 2001). In the present study the magnitude of a low-flow in the Meuse is represented in terms of the average summer discharge $\left(Q_{\text {avgs }}\right)$ and the discharge deficit volume accumulated over the season $\left(Q_{\text {def }}\right)$. These seasonal low-flow indices are less sensitive to the human-induced fluctuations. $Q_{\text {avgs }}$ is calculated for the period May to October (summer half-year) for each year in the 1911-2003 record. $Q_{\text {def }}$ is calculated from the daily average discharge $Q_{\text {day }}$ as the sum of $\left(Q_{\text {threshold }}-Q_{\text {day }}\right)$ for all days with $Q_{\text {day }}<Q_{\text {threshold }} \cdot Q_{\text {def }}$ is measured with a threshold value of $60 \mathrm{~m}^{3} \cdot \mathrm{s}^{-1}$. Below this critical level the discharge of the Meuse is too low to fulfil all functions in the Dutch/Flemish Meuse and the connected canals. Most water users have reserves to overcome short periods with a lack of (clean) water. Economic losses expand when low-flow periods lasts for several weeks or even months and the buffer capacity is exhausted. From the perspective of water users $Q_{\text {def }}$ is a useful low-flow index since it integrates information on the length and the magnitude of low-flow events.

During 1911-2003 $Q_{\text {threshold }}$ was exceeded $92 \%$ of the time and thus corresponds to $Q 8$. Table 1 shows that discharges below $60 \mathrm{~m}^{3} \mathrm{~s}^{-1}$ typically occur during the summer and autumn, and have never been recorded during March nor April. A comparison of $Q_{\text {def }}$ calculated for the periods May to October (summer half-year) and May to April (whole year) revealed a strong correlation, owing to the dominant occurrence of days with discharge $<60 \mathrm{~m}^{3} \mathrm{~s}^{-1}$ in the May to October period. In the following sections only the 'summer half-year' value of $Q_{\text {def }}$ is used.

Table 1 Water stress in the Meuse

\begin{tabular}{lllllllllllll}
\hline Month & Jan & Feb & Mar & Apr & May & Jun & Jul & Aug & Sep & Oct & Nov & Dec \\
\hline Days $(n)$ & 14 & 5 & 0 & 0 & 29 & 136 & 351 & 578 & 688 & 626 & 236 & 73 \\
\hline
\end{tabular}

Total number of days with a critical discharge rate of less than $60 \mathrm{~m}^{3} \mathrm{~s}^{-1}$ (Borgharen $_{\mathrm{cor}}$ ) during 1911-2003. 


\subsection{Meteorological data (1911-2003)}

Precipitation data for the period 1911-2003 from eight stations in Central and Eastern Belgium were provided by the Royal Meteorological Institute of Belgium. Information about the location, origin and quality of these data can be found in Demarée et al. (1994). Daily temperature data for Maastricht (The Netherlands), Uccle (Belgium), Paris (France), and Karlsruhe (Germany) covering the period 1911-2003, are taken from the European Climate Assessment (ECA) dataset (Klein Tank et al. 2002). This dataset comprises daily resolution climatic time series. For the period 1968-1998 more detailed meteorological data for the Meuse basin were available. For this period, area average daily precipitation, temperature and potential evapotranspiration data have been used for 15 sub-basins of the Meuse catchment upstream from Borgharen. These sub-basin average values are based on data from a large number of stations within the sub-basins (see Leander et al. 2005). The Royal Meteorological Institute of Belgium and Meteo France provided the original data. The detailed 1968-1998 dataset has been used to validate the quality of the 1911-2003 basin average precipitation and temperature records for the overlapping period. The 1968-1998 dataset has also been used as input for the hydrological simulations with the HBV model.

\subsection{Statistical analysis (1911-2003)}

Correlation coefficients are calculated to assess the relationships between half-year precipitation and temperature anomalies, and the average discharge during the summer half-year. Such analysis will indicate to what extent low flows in the summer half-year correlate to precipitation and temperature in the foregoing winter half-year and/or precipitation and temperature in the summer half-year. This analysis is based on the full observed record period (1911-2003). The monthly precipitation and temperature values have been averaged for all stations and for each winter half-year (November to April) and summer half-year (May to October) season. The seasonal values for the winter half-year are assigned to the same hydrological year as the subsequent summer half-year. Anomalies of seasonal precipitation $\left(P^{\prime}\right)$ and temperature $\left(T^{\prime}\right)$ were calculated based on these data. Firstly the anomalies relative to the 1968-1998 period were calculated using both the 1911-2003 and 1968-1998 datasets. It appears that the anomalies based on the relatively coarse 1911-2003 dataset are in good agreement with those derived from the far more detailed 1968-1998 dataset. This means that the limited number of stations used in the 1911-2003 precipitation and temperature records has only a minor effect on the quality of the estimation of seasonal precipitation and temperature anomalies.

\subsection{HBV model for the Meuse basin}

The conceptual hydrological model HBV was developed in the early 1970s (Bergström and Forsman 1973) and has been applied to many catchments around the world (Lindström et al. 1997). HBV describes the most important runoff generating processes with simple and robust structures. In the snow routine, snow accumulation and melting are determined using a temperature-index method. The soil routine divides rainfall and meltwater between runoff generation and soil storage for later evaporation. The runoff generation routine consists of one upper non-linear reservoir representing fast runoff components, and one 
lower linear reservoir representing base flow. Runoff routing processes are simulated using a simplified Muskingum approach. HBV is a semi-distributed model and the river basin can be subdivided into sub-basins. HBV simulates the rainfall-runoff processes for each subbasin separately with a daily time step. The Meuse basin upstream of Borgharen has been subdivided into 15 sub-basins. Further details about the HBV model can be found on the website of the Swedish Meteorological and Hydrological Institute (http://www.smhi.se).

The HBV model has recently been used in a number of hydrological studies of the river Meuse (Booij 2005; Leander et al. 2005; Ashagrie et al. 2006). Moreover, HBV is used by the Dutch flood forecast centre as the hydrological component of a recently developed flood early warning system for the rivers Rhine and Meuse. HBV has been run on a daily basis using daily temperature, precipitation, potential evapotranspiration and discharge data for the period 1968-1984 (calibration) and 1985-1998 (validation) by Booij (2002, 2005) and fine-tuned (with more detailed data) by Van Deursen (2004). The schematisation derived from Van Deursen (2004) is used in this study. The results have been evaluated against observed discharge records in terms of volume errors $\left(\mathrm{mm} \cdot \mathrm{year}^{-1}\right)$ and NashSutcliffe coefficients (Nash and Sutcliffe 1970) for gauging stations along the Meuse and the outlets of sub-basins. Nash-Sutcliffe coefficients of around 0.9 were obtained. The Nash-Sutcliffe coefficient for Borgharen was 0.93 for the validation period 1985-1998. This period includes the extreme flood events of December 1993 and January 1995, which were well simulated by the HBV model (see Fig. 2). The total discharge volume error over the entire validation period was just $1 \%$. Monthly average discharges were well simulated for the months with the highest (January) and lowest (August) discharge. However, the monthly average discharges were generally overestimated during spring and underestimated during autumn (see Fig. 3).

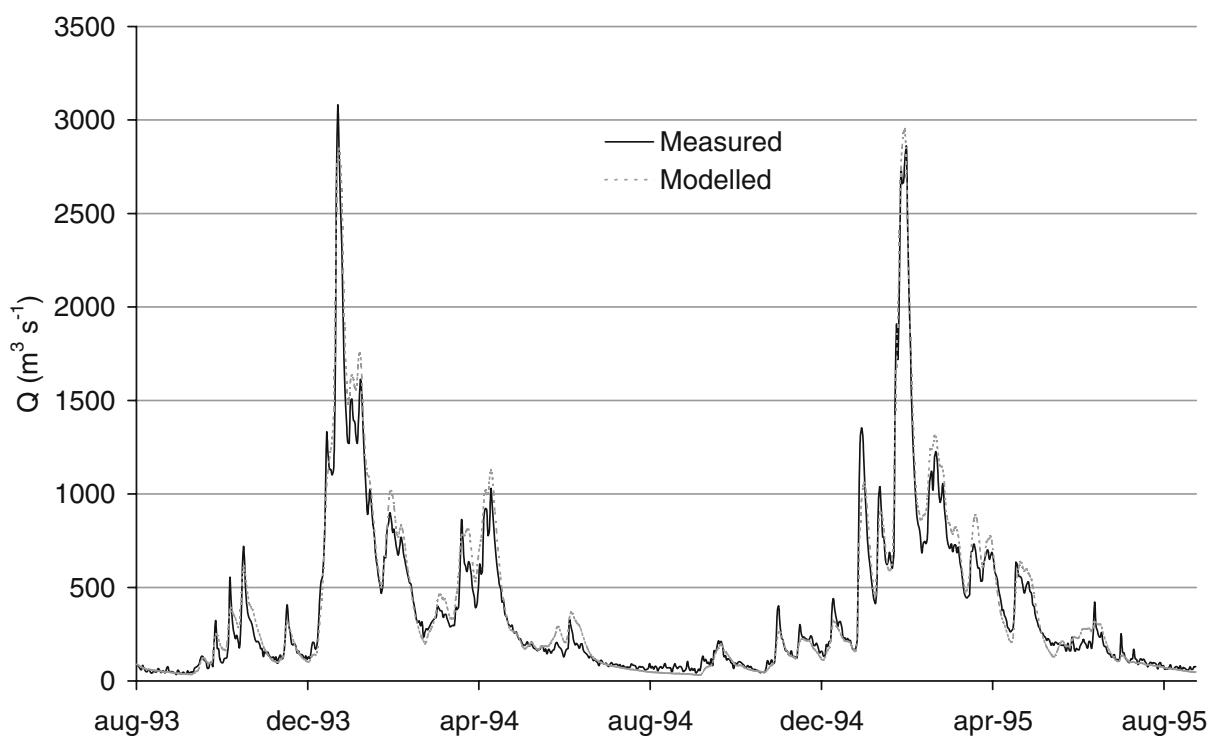

Fig. 2 Modelled and measured daily average discharge August 1993-August 1995 


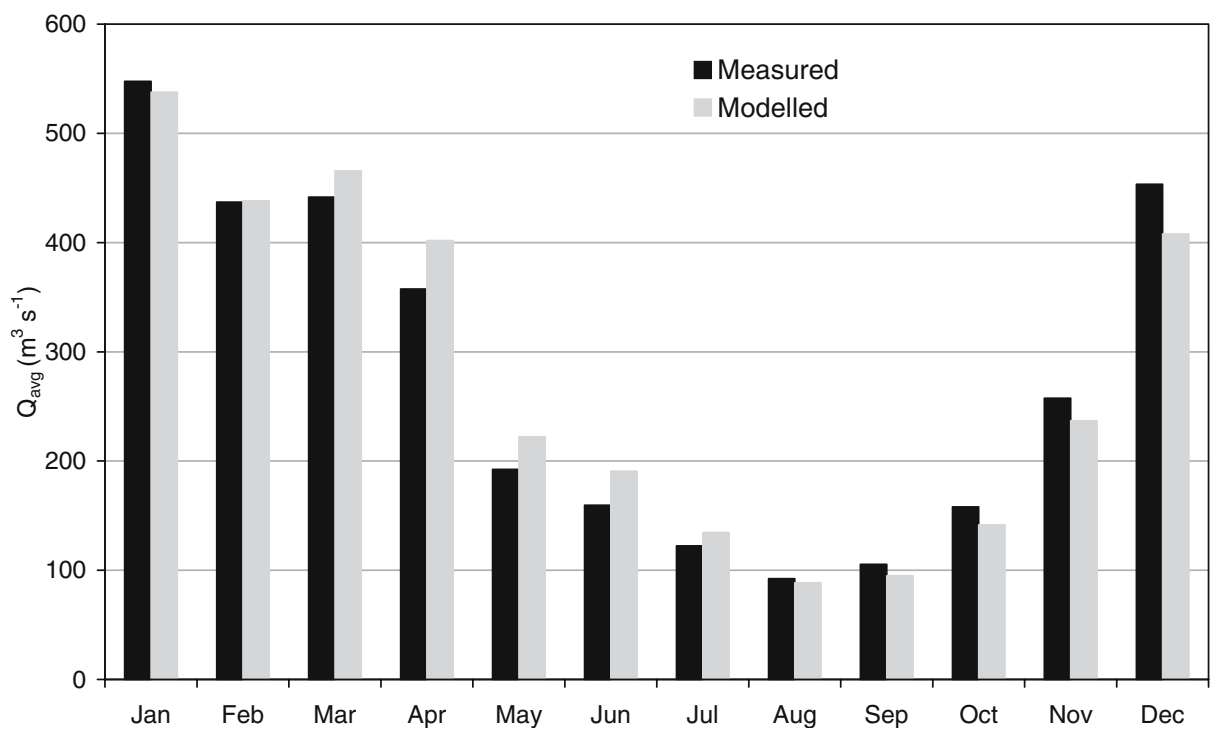

Fig. 3 Modelled and measured monthly average discharge (1985-1998)

\subsection{Regional climate models}

Climate change scenarios are developed using a range of GCM simulations forced by various greenhouse gas emissions scenarios (IPCC 2001). Downscaling to the regional scale is considered necessary because of the coarse resolution of GCMs. A comprehensive set of RCM simulations has been prepared for the European area as part of the PRUDENCE project (Prediction of Regional scenarios and Uncertainties for Defining EuropeaN Climate change risks and Effects; Christensen et al. 2002). Each RCM covered either the whole of, or part of, Europe (all included the Meuse basin) at a spatial resolution of typically $50 \times$ $50 \mathrm{~km}$. The ensemble of climate simulations contained seven RCMs, driven by two different GCMs which performed transient simulations for the 1960-2100 period assuming a so-called SRES A2 greenhouse gas emissions scenario (IPCC 2001). The RCMs simulated two time slices in these transient GCM simulations: 'present day' (1960-1990) and future (2070-2100). Two RCMs were driven with GCM simulations from both the Max Planck Institute (ECHAM4/OPYC) and the UK Hadley Centre (HadAM3H). The remaining RCMs used only the HadAM3H GCM boundary conditions. More details about the simulations and verification of the results is presented by Christensen et al. (2002); Jacob et al. (2007), and the website mentioned in the reference list.

\section{RCM scenarios for the Meuse basin}

Figure 4 presents the differences of monthly average precipitation and temperature between the 30-year control runs (1960-1990) and the 30-year scenario runs (2070-2100) for each of the nine RCM simulations. It appears that the difference between the RCMs driven by the same GCM is smaller than the difference between the same RCMs driven 
by different GCMs. The simulations agree on a general increase in winter precipitation and a general decrease in summer precipitation. The simulations also suggest an increase in annual average temperature of between 3 and $6^{\circ} \mathrm{C}$, with increases in summer temperatures relatively greater than those of winter temperatures. These results are consistent with the findings of Van den Hurk et al. (2005) for the Rhine basin, and Déqué et al. (2005) for Northwest Europe. For a more complete overview of the results of climate change simulations for Europe see Raïsänen et al. (2004), several papers in an upcoming
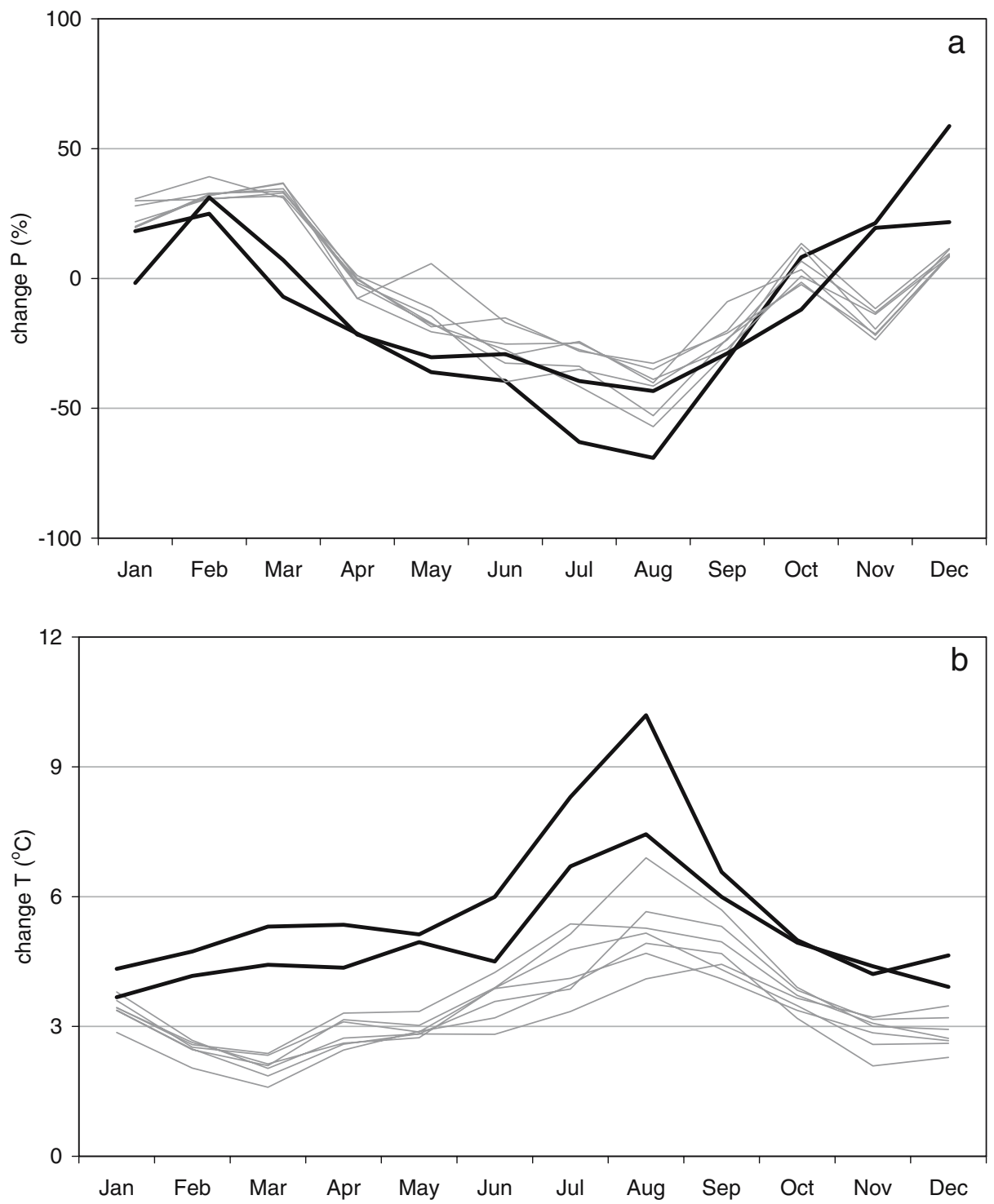

Fig. 4 Change in monthly precipitation (a) and temperature (b) in the Meuse basin derived from nine RCM simulations. Bold lines are RCMs driven by ECHAM4/OPYC, thin lines are RCMs driven by HadAM3H 
Table 2 Relative difference in seasonal precipitation and temperature values between measurements and RCM control runs

\begin{tabular}{llllllllllll}
\hline & Season & \multicolumn{1}{l}{ RCMs driven by HadAM3H } & & \multicolumn{3}{c}{$\begin{array}{l}\text { RCMs driven by ECHAM4/ } \\
\text { OPYC }\end{array}$} \\
\hline & & & & & & & \\
& & UCM & SMHI & MPI & KNMI & GKSS & ETH & DMI & SMHI & DMI \\
Pdif. (\%) & Winter & -2 & 19 & 4 & 26 & -3 & -5 & 8 & 24 & 18 \\
& Summer & -14 & 0 & 2 & 4 & -22 & -27 & -1 & 22 & 27 \\
Tdif. ( $\left.{ }^{\circ} \mathrm{C}\right)$ & Winter & 0.3 & 1.9 & 1.4 & 1.6 & -0.2 & 0.8 & 1.2 & 1.4 & 0.7 \\
& Summer & -1.1 & 1.6 & 1.5 & 1.0 & -0.6 & 0.4 & 1.1 & 0.9 & -0.1 \\
\hline
\end{tabular}

special issue of Climatic Change (to appear in 2007), and the website of the PRUDENCE project.

Seasonal precipitation volumes have been derived from the RCM control runs (19601990 ) in a similar manner as for the observed records. There appear to be large differences between the results obtained from the various RCMs. As shown in Table 2, the RCMs generally overestimate average winter precipitation and temperature in the Meuse basin. The average summer precipitation is underestimated by some RCMs and overestimated by others. Summer precipitation is overestimated by, the RCMs driven by ECHAM4/OPYC in particular.

\section{Statistical analysis}

The observed winter and summer half-year average temperature $\left(T^{\prime}\right)$ and precipitation $\left(P^{\prime}\right)$ anomalies for the period 1911-2003 are shown in Figs. 5 and 6. The observed average summer half-year discharge $\left(Q_{\text {avgs }}\right)$ is shown in Fig. 7, and summer half-year $Q_{\text {def }}$ is shown in Fig. 8. Hisdal et al. (2001) analysed 600 daily streamflow records throughout Europe and concluded that low-flow events have not become more severe or frequent during the twentieth century. The records presented in Figs. 7 and 8 also give no indication of an increase in the occurrence of low-flows in the Meuse basin.

In Table 3 correlation coefficients are presented to assess the relationships between winter and summer half-year precipitation and temperature anomalies, and average discharge during the summer half-year. For all variables the values for the summer halfyear have been compared to the values for the preceding winter half-year. As shown in Table 3, temperature and precipitation anomalies for successive seasons are not significantly related. There appears to be a weak but significant relationship between $T^{\prime}$ and $P^{\prime}$ within the same season. This relationship is positive $\left(8 \%{ }^{\circ} \mathrm{C}^{-1}\right)$ for the winter halfyear and negative $\left(-11 \%{ }^{\circ} \mathrm{C}^{-1}\right)$ for the summer half-year. A large part of the variance of $Q_{\text {avgs }}$ can be attributed to the variance of summer precipitation $(r=0.70)$. $Q_{\text {avgs }}$ also shows a weak but significant correlation with summer temperature, as well as with precipitation in the preceding winter half-year.

The influence of winter precipitation volume on the discharge deficit volume $\left(Q_{\text {def }}\right)$ in the subsequent summer is illustrated in Fig. 9. The size of the dots in Fig. 9 is related to the magnitude of $Q_{\mathrm{def}}$ in a specific year. In Fig. 9 it can be seen that a prediction of the magnitude of $Q_{\text {def }}$ based on $P^{\prime}{ }_{\text {winter }}$ and $P^{\prime}$ summer alone is not very accurate. However, it appears that the most critical low-flows in the Meuse basin $\left(Q_{\text {def }}>100\right.$ million $\mathrm{m}^{3}$, see also 

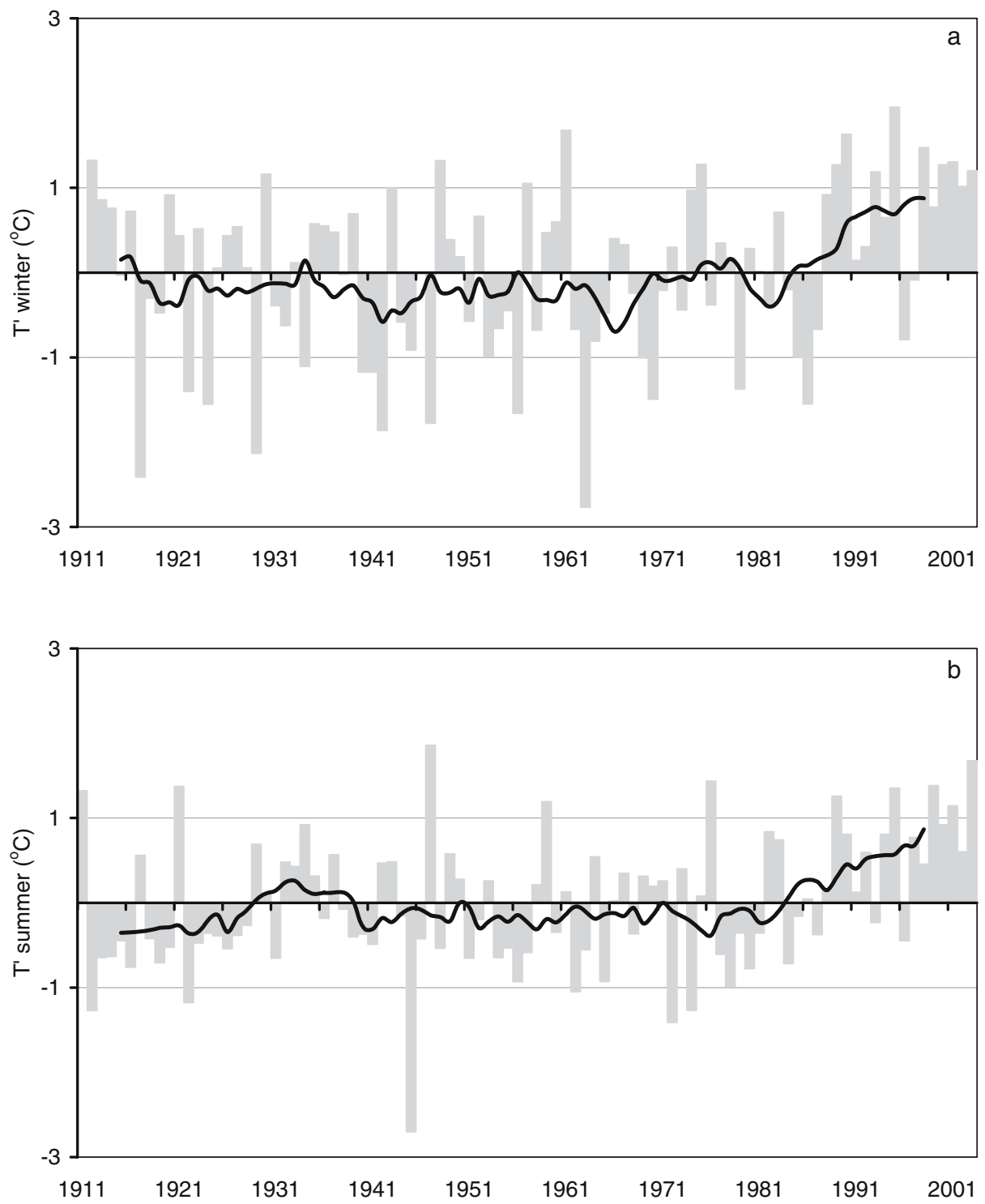

Fig. 5 Seasonal temperature anomalies $\left(T^{\prime}\right)$ for the winter half-year (a) and summer half-year (b) relative to the period 1911-2003. The line is the moving average (window 10 years)

Fig. 8) occur in years with subsequent dry winters and dry summers. Such low-flow events have neither been observed in years when a dry winter was followed by a wet summer, nor in years when a wet winter was followed by a dry summer.

Figure 10 duplicates Fig. 9, but includes the precipitation anomalies derived from the nine 30-year control and 30-year scenario RCM runs. The anomalies for the control runs and the scenario runs are calculated relative to the average value for the control runs to correct for the biases presented in Table 2. Note that in Fig. 10 all of the different RCM 

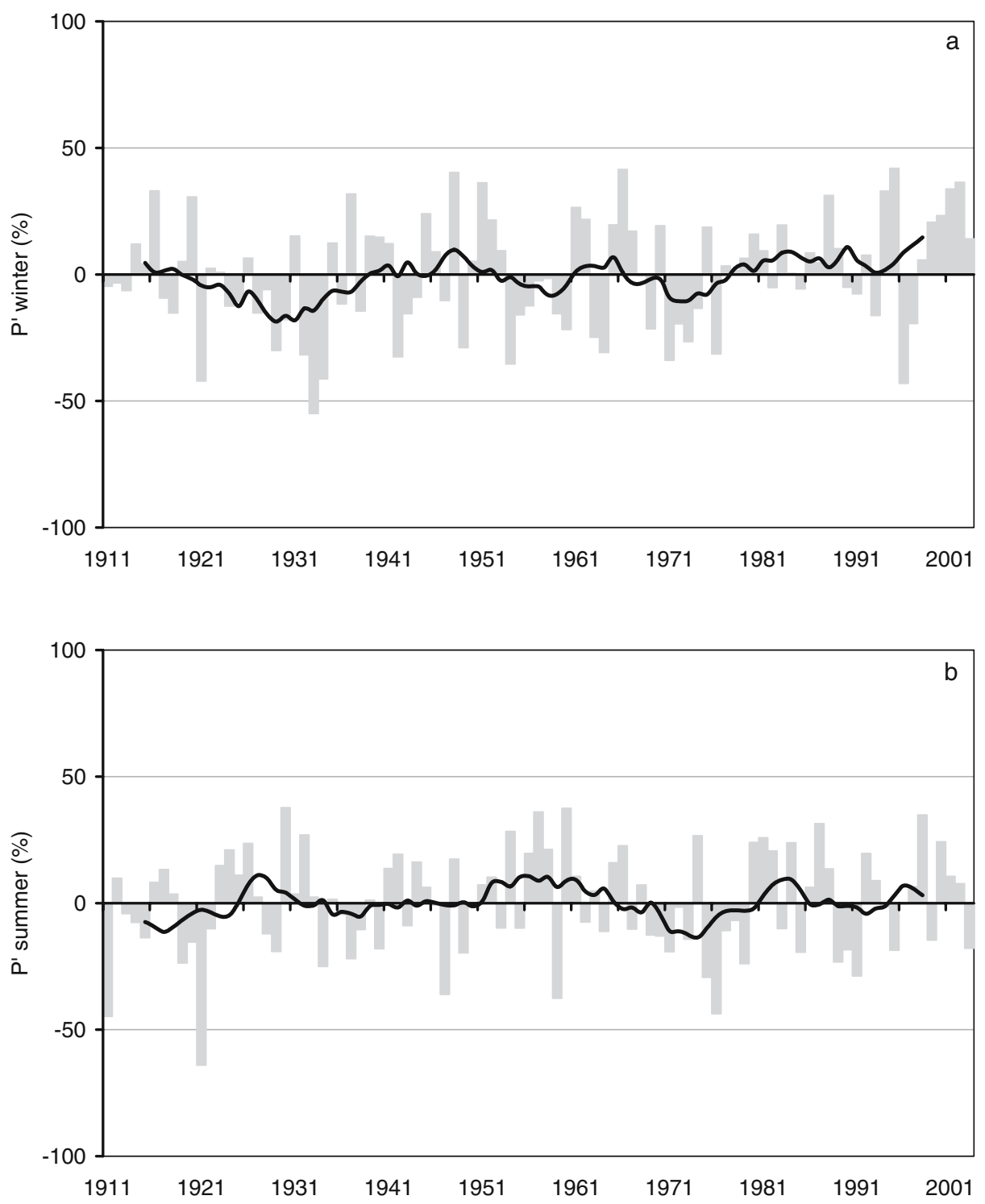

Fig. 6 Seasonal precipitation anomalies $\left(P^{\prime}\right)$ for the winter half-year (a) and summer half-year (b) relative to the period 1911-2003. The line is the moving average (window 10 years)

runs have been plotted with the same symbol. However, there appeared to be large differences between the results obtained from different RCM runs (see also Table 2). There is good agreement between the observed and simulated variability of winter and summer precipitation anomalies. This lends support to the use of RCM simulations in the assessment of seasonal precipitation anomalies under future climate change scenarios. In agreement with the results presented in Fig. 4 the scenario runs show an increase in the occurrence of years with a wet winter followed by a dry summer. The symbols in Fig. 10 


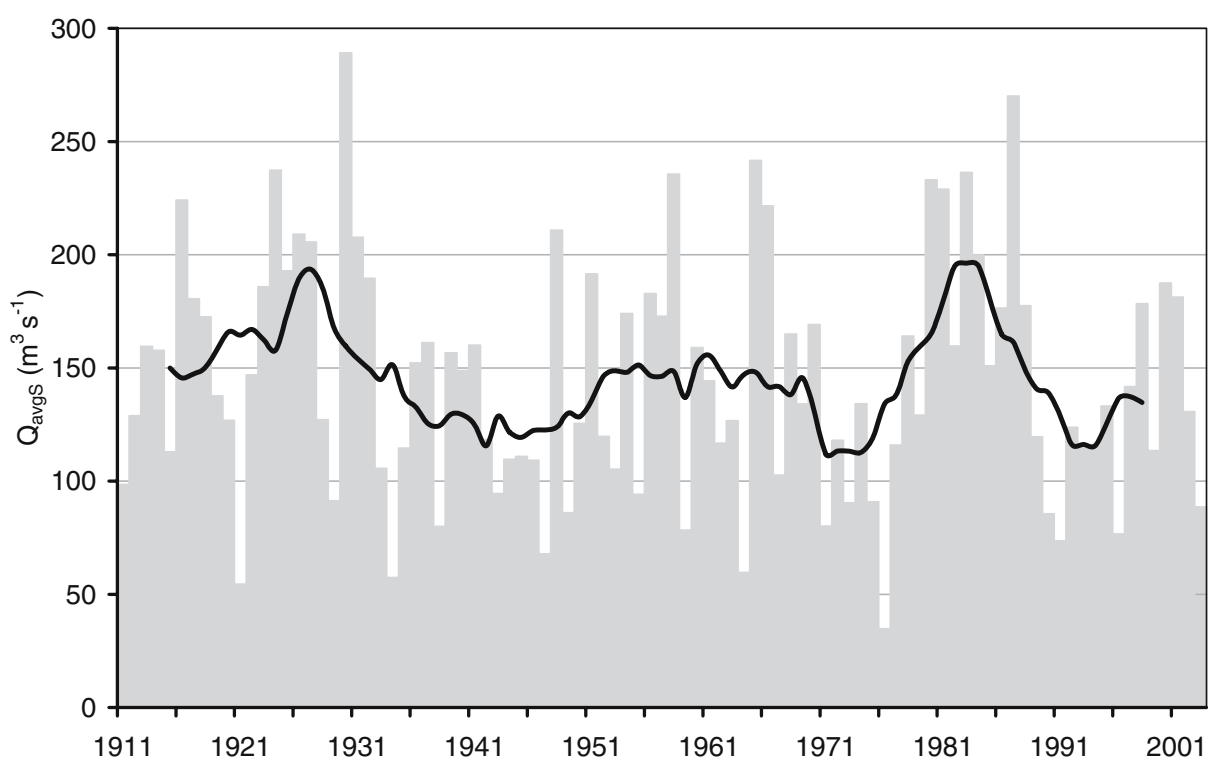

Fig. 7 Measured average discharge summer half-year $\left(Q_{\text {avgs }}\right)(1911-2003)$. The line is the moving average (window 10 years)

therefore cluster in a downwards and right direction. The scenario runs result in many dots (years) located outside the range of the (multi-seasonal) observations from the 1911-2003 dataset. Based on this explorative study one cannot conclude whether such years will produce large discharge deficits in the Meuse during the summer. For all the years in the period 1911-2003 in which $Q_{\text {def }}>100$ million $\mathrm{m}^{3}$, both $P^{\prime}{ }_{\text {winter }}$ and $P_{\text {summer }}^{\prime}$ are negative. For both the observations, the corrected control runs and the scenario runs such conditions occur about once every four years. There is no indication that the occurrence of years with subsequent dry winters and dry summers (e.g., years resembling 1921 and 1976) will increase. Also, the correlation between summer precipitation and winter precipitation is not shown to clearly change under future greenhouse gas concentration conditions (see Table 4).

An interesting year from the observational record is 2003. The precipitation anomalies $\left(P_{\text {winter }}^{\prime}+14 \%, P_{\text {summer }}^{\prime}-18 \%\right)$ for 2003 resemble an average year at the end of the twenty-

Table 3 Correlation coefficients $(r)$ for seasonal precipitation and temperature anomalies 1911-2003 $(n=92)$

\begin{tabular}{llllll}
\hline & $\begin{array}{l}T^{\prime}\left({ }^{\circ} \mathrm{C}\right) \\
(\text { winter})\end{array}$ & $\begin{array}{l}T^{\prime}\left({ }^{\circ} \mathrm{C}\right) \\
(\text { summer })\end{array}$ & $\begin{array}{l}P^{\prime}(\%) \\
(\text { winter })\end{array}$ & $\begin{array}{l}P^{\prime}(\%) \\
(\text { summer })\end{array}$ & $\begin{array}{l}Q_{\text {avgs }} \\
\left(\mathrm{m}^{3} \mathrm{~s}^{-1}\right) \\
(\text { summer })\end{array}$ \\
\hline$T^{\prime}\left({ }^{\circ} \mathrm{C}\right)$ (winter) & - & 0.14 & $\mathbf{0 . 3 7}$ & 0.06 & 0.04 \\
$T^{\prime}\left({ }^{\circ} \mathrm{C}\right)$ (summer) & & - & -0.10 & $-\mathbf{0 . 4 1}$ & $-\mathbf{0 . 3 4}$ \\
$P^{\prime}(\%)$ (winter) & & & - & 0.13 & $\mathbf{0 . 3 6}$ \\
$P^{\prime}(\%)$ (summer) & & & - & $\mathbf{0 . 7 0}$ \\
\hline
\end{tabular}

Bold values are significant at $5 \%$. 


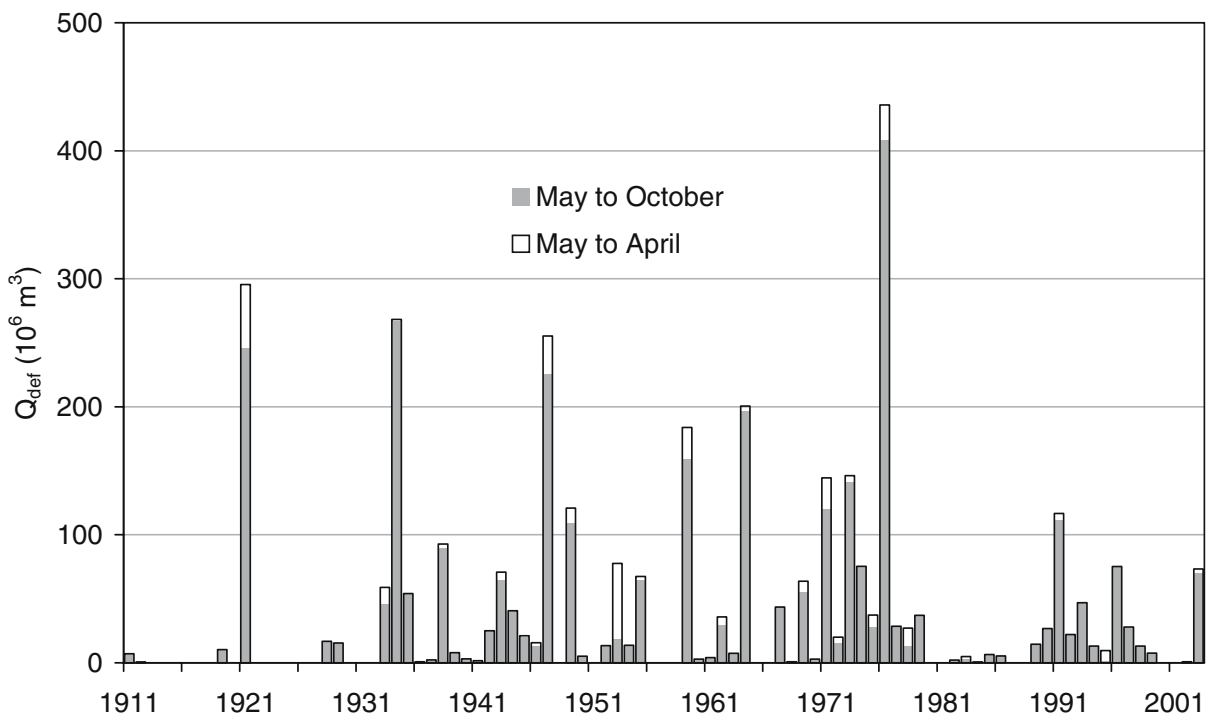

Fig. 8 Measured discharge deficit volume $\left(Q_{\text {def }}\right)$ (1911-2003) for the summer half-year (May-Oct) and entire year (May-Apr)

first century suggested by the RCM scenario runs. During the summer of 2003 a recordbreaking heat wave affected the European continent. In a large area of Europe, mean summer (June, July, August) temperatures exceeded the $1961-1990$ mean by $3^{\circ} \mathrm{C}$, corresponding to an excess of five standard deviations from the mean (Schär et al. 2004). Schär et al. (2004) argue that the anomalous summer of 2003 fits the picture of increased

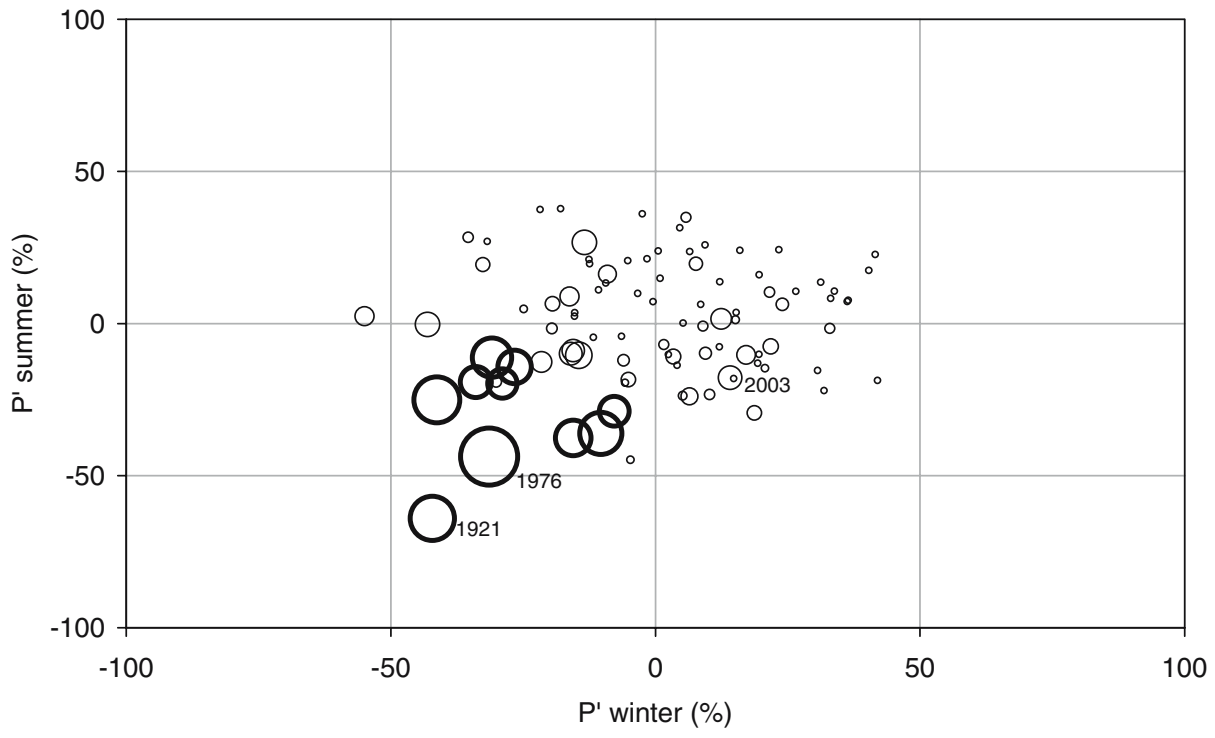

Fig. 9 Scatter diagram of observed winter half-year and subsequent summer half-year precipitation anomalies (1911-2003). The size of the circles is a measure of $Q_{\mathrm{def}}$ in the summer half-year year. Bold circles are years with $Q_{\text {def }}>100 \mathrm{Mm}^{3}$ 


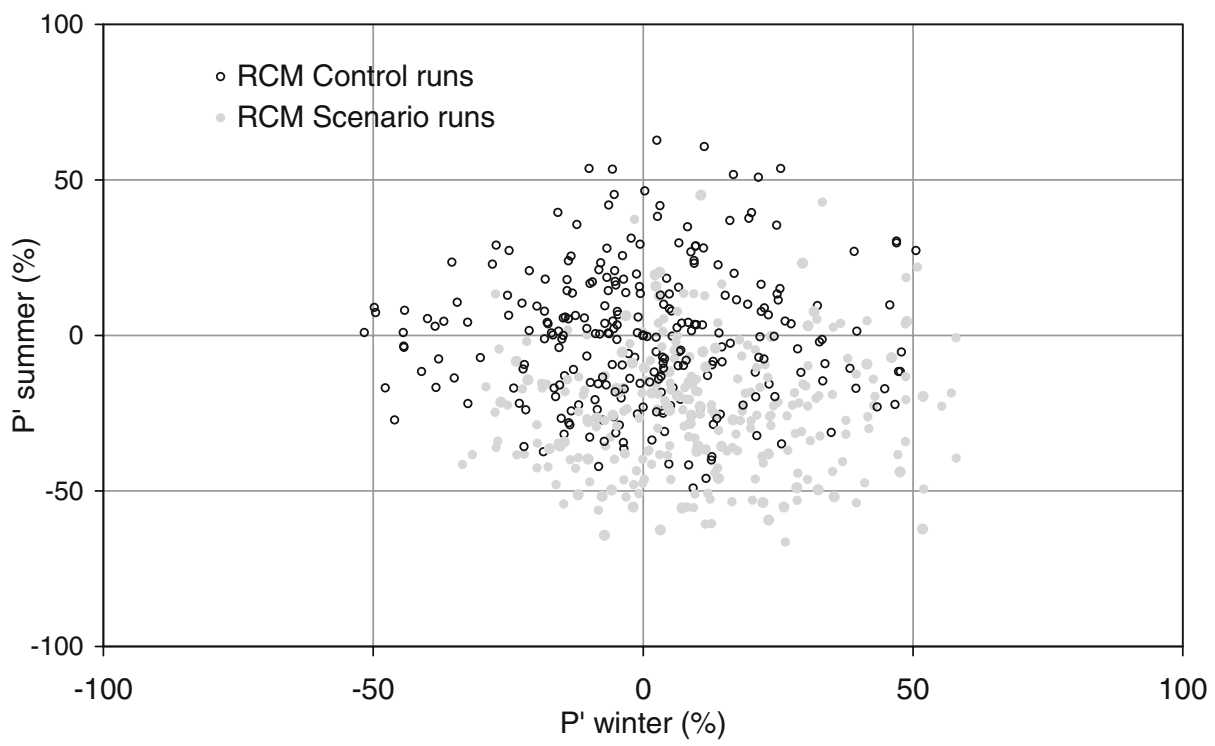

Fig. 10 Scatter diagram of observed (1911-2003) and simulated (1960-1990 and 2070-2100) winter halfyear and subsequent summer half-year precipitation anomalies

inter-annual variability of summer temperatures, which was also simulated by the PRUDENCE RCM experiments. The magnitude of the observed 2003 temperature anomaly is consistent with the mean temperature change in the RCM ensemble, indicating that a summer like that of 2003 is to be considered 'normal' for the climate represented by the RCM scenario runs. The Meuse basin is located close to the area with the largest

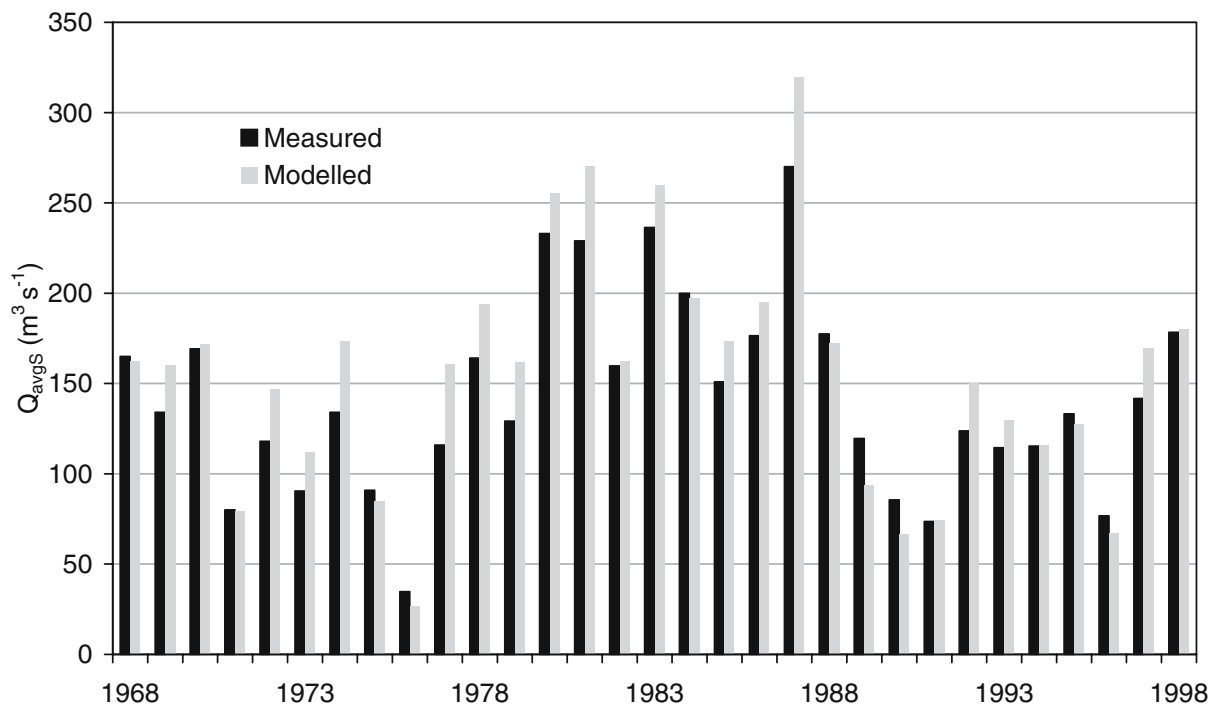

Fig. 11 Measured and modelled average summer half-year discharge ( $\left.Q_{\text {avgs }}\right)$ (1968-1998) 
Table 4 Correlation coefficients $(r)$ for simulated winter and subsequent summer precipitation anomalies $(n=30)$

\begin{tabular}{|c|c|c|c|c|c|c|c|c|c|}
\hline \multirow[t]{2}{*}{ Run } & \multicolumn{6}{|c|}{ RCMs driven by HadAM3H } & \multicolumn{2}{|c|}{$\begin{array}{l}\text { RCMs driven by ECHAM4/ } \\
\text { OPYC }\end{array}$} & \multirow[t]{2}{*}{ Average } \\
\hline & UCM SMHI & MPI & KNMI & GKSS & ETH & DMI & SMHI & DMI & \\
\hline Control & $0.061 \quad 0.093$ & 0.075 & 0.036 & 0.224 & 0.136 & 0.131 & -0.224 & -0.492 & 0.004 \\
\hline Scenario & 0.0720 .002 & 0.226 & 0.072 & 0.130 & -0.079 & -0.215 & 0.284 & 0.448 & 0.104 \\
\hline
\end{tabular}

Bold values are significant at $5 \%$.

anomaly. Note that the temperature anomaly shown in Fig. $5\left(+1.7^{\circ} \mathrm{C}\right)$ was calculated for a 6-month period.

\section{Hydrological simulation}

There is a strong correlation $(r=0.96)$ between measured and modelled $Q_{\text {avgs }}$ in the period 1968-1998 (Fig. 11). However, the model systematically overestimates $Q_{\text {avgs }}$ by an average of $12 \mathrm{~m}^{3} \mathrm{~s}^{-1}(9 \%)$. Furthermore, it appears that the correlation of $Q_{\mathrm{avgs}}$ with $P_{\text {winter }}^{\prime}$ in the period 1968-1998 is lower for the simulated discharge $(r=0.38)$ than for the observed discharge $(r=0.48)$. This suggests that the HBV model somewhat underestimates the influence of winter precipitation on average summer discharge. The average measured $\mathrm{Q}_{\mathrm{def}}$ is 42 million $\mathrm{m}^{3}$, whereas the average modelled $\mathrm{Q}_{\mathrm{def}}$ is 73 million $\mathrm{m}^{3}$. This implies that the model overestimates the magnitude of water stress in the river Meuse by almost $75 \%$ for the period 1968-1998 (Fig. 12). Figure 13 shows a section of the curve in Fig. 2 in more detail, namely the measured and modelled daily discharge record for the Meuse in the period May to October 1994. The deviations are hardly visible when looking at the seasonal discharge pattern (Fig. 2), but appear relatively large when one is specifically interested in critical

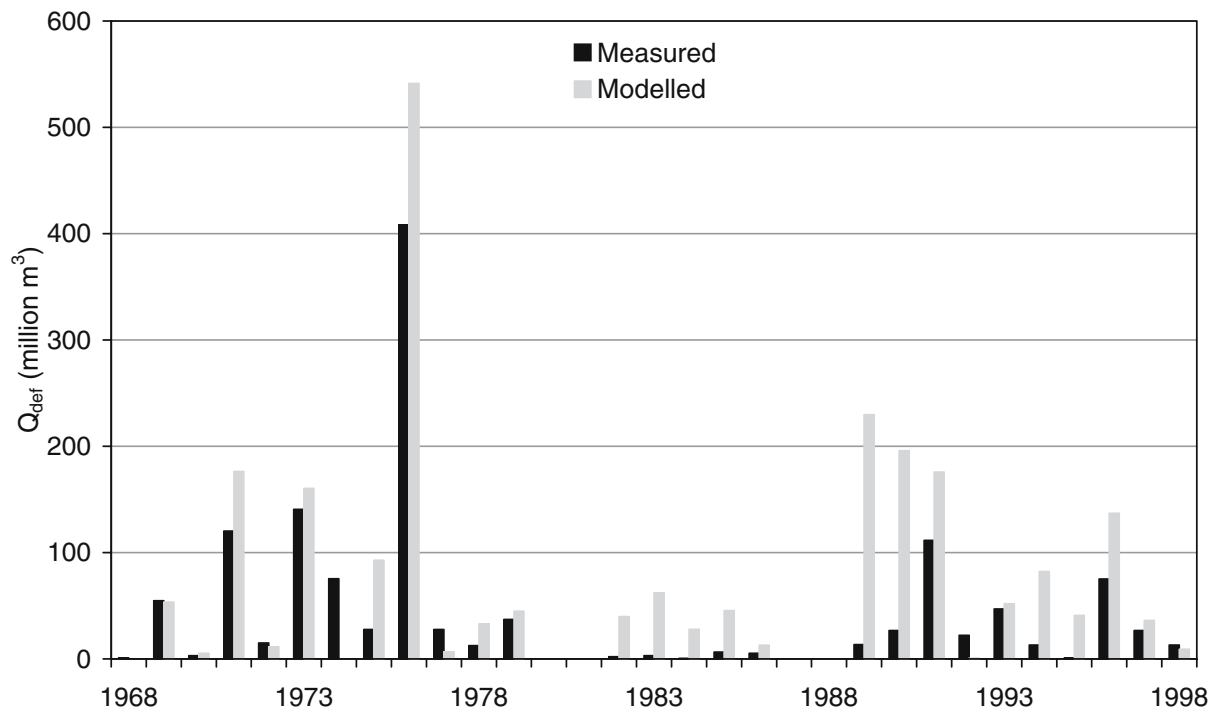

Fig. 12 Measured and modelled discharge deficit volume $\left(Q_{\mathrm{def}}\right)(1968-1998)$ 


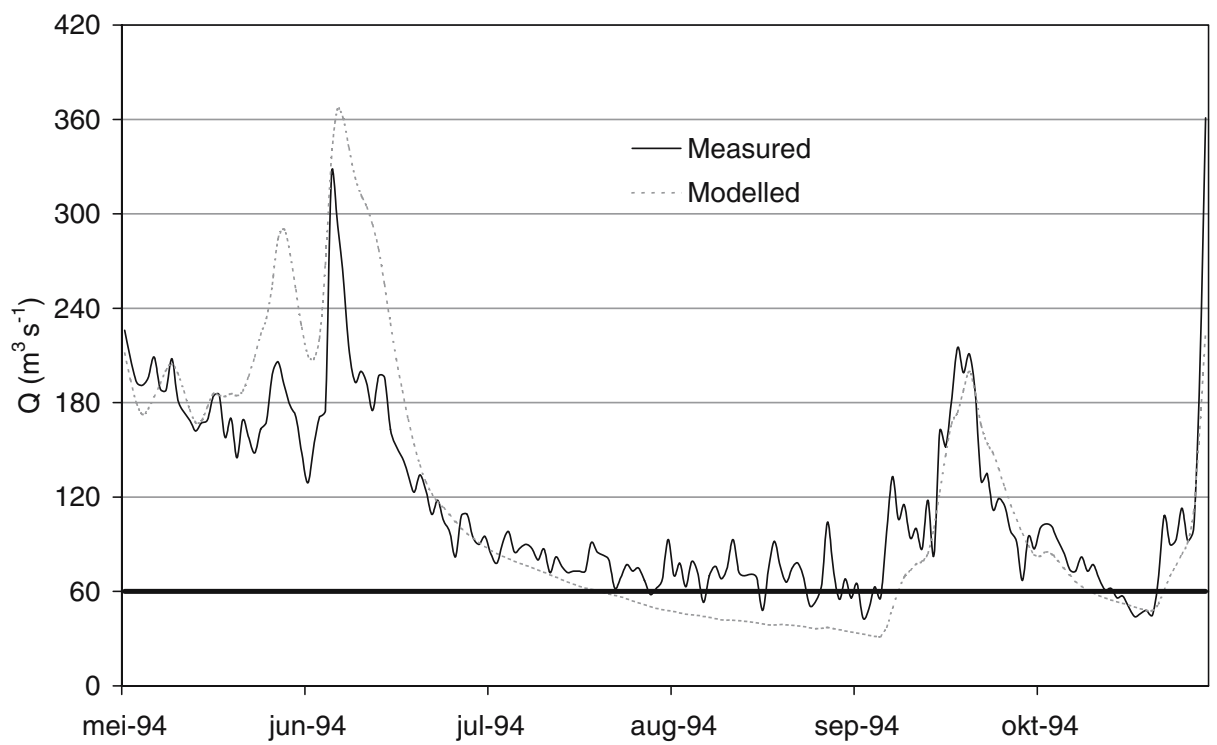

Fig. 13 Measured and modelled daily average discharges summer 1994

low-flows $\left(Q<60 \mathrm{~m}^{3} \mathrm{~s}^{-1}\right)$. Similar deviations between modelled and measured low-flows are observed for the other low-flow periods in the 1968-1998 record.

The modelled low-flow hydrograph is much smoother than the measured low-flow hydrograph (see Fig. 13). This can partly be explained by human-induced discharge fluctuations (e.g., operation of weirs and reservoirs) that are not included in the model schematisation. It also appears that in HBV most of the summer precipitation infiltrates the surface, whereas in reality summer precipitation often results in small but fast responses in river discharge. Optimising the HBV parameters that determine the distribution of surface infiltration and direct runoff during the summer will have a strong impact on model performance during the winter (Booij 2005).

Another systematic difference that can be observed in the measured and modelled hydrographs is the declining slope during low-flow periods. In the measured hydrographs the minimum discharge more or less levels off halfway through the low-flow period (e.g., at 50$60 \mathrm{~m}^{3} \mathrm{~s}^{-1}$ for the summer of 1994), whereas the modelled minimum discharge decreases throughout the low-flow period (e.g., as low as $30 \mathrm{~m}^{3} \mathrm{~s}^{-1}$ for the summer of 1994). Within HBV the heterogeneous sub-surface is represented by only two reservoirs per sub-basin $\left( \pm 1,000 \mathrm{~km}^{2}\right)$. The discharge of these reservoirs is schematised by lumped parameters. This schematisation may not be detailed enough to simulate the complex non-linear processes that determine the delayed flow in the Meuse basin. It should also be noted that the Borgharen record is based on observed discharges that have been subjected to a correction factor to account for water extractions between Borgharen and Liège (see Section 3). During lowflows a large proportion of the discharge of the 'undivided Meuse' is diverted to the canals. Hence, errors in the applied extraction rates can have a substantial effect on the Borgharen cor $_{\text {. }}$ record. Part of the deviation between measured and modelled discharges during low-flows may therefore potentially be explained by errors in the Borgharen cor $_{\text {record. }}$

To explore the impact of future climate conditions on summertime low flows, the precipitation and temperature data derived from the control and scenario runs of the KNMI RCM 


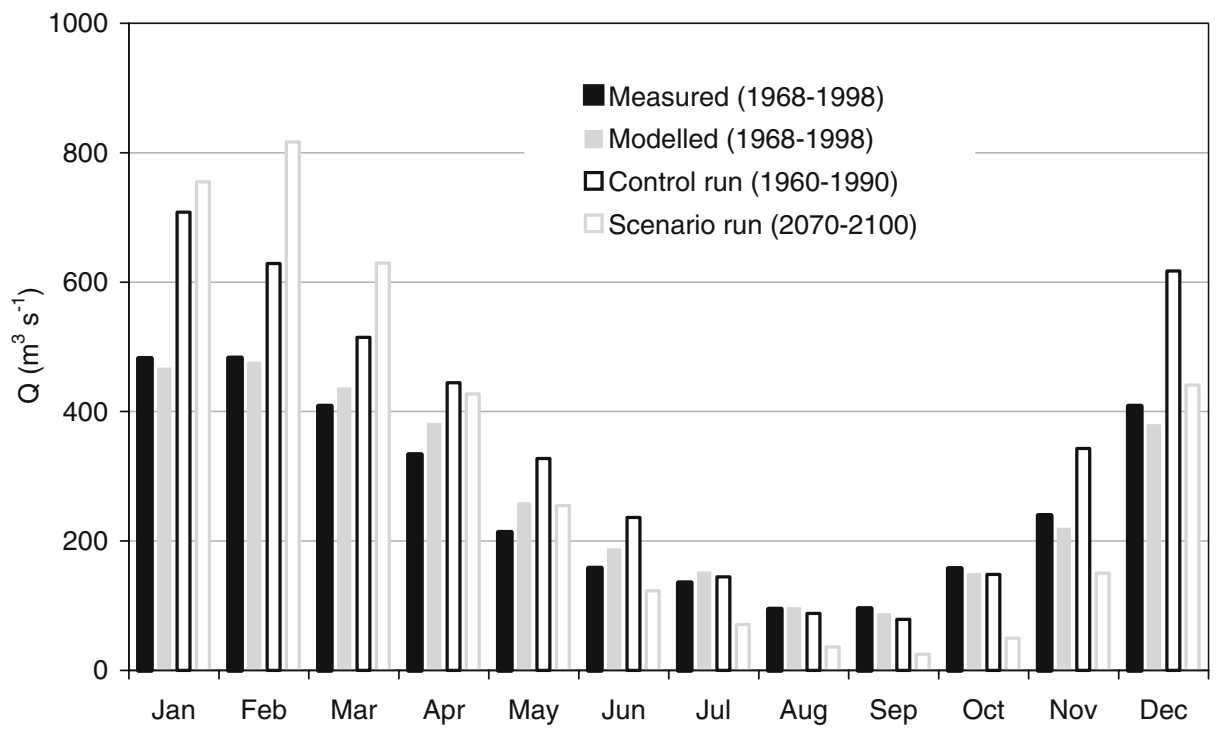

Fig. 14 Modelled and measured monthly average discharge

have been used as input for the HBV model. The average monthly discharge regimes simulated by these runs are shown in Fig. 14. The control run simulates much higher discharges than the run using measured precipitation data. This can be explained by the bias in winter precipitation in the control run $(+26 \%)$ as presented in Table 2 . The average summer discharge $\left(Q_{\text {avgs }}\right)$ in the scenario run is half of that observed in the control run. This illustrates that the projected increase of winter precipitation and decrease of summer precipitation (see Fig. 4) will enhance the seasonality in the discharge regime of the river Meuse.

The simulated average values of $Q_{\text {def }}$ are shown in Table 5. The $Q_{\text {def }}$ values for the HBV run with measured precipitation and the HBV run with precipitation derived from the control run (26\% more winter precipitation), are almost the same. This illustrates that within the HBV model winter precipitation volume does not substantially affect the magnitude of $Q_{\text {def }}$ in the summer. This is not in agreement with the observations presented in Fig. 9. The average discharge deficit volume increases fourfold in the scenario run. However, the model results for the period 1968-1998 (Figs. 12 and 13 and Table 5) point to a number of problems that must be solved before reliable simulations of the impact of climatic change on critical low-flows in the Meuse can be performed.

Table 5 Measured and simulated average discharge deficit $\left(Q_{\mathrm{def}}\right)$

\begin{tabular}{lll}
\hline & Period & $\begin{array}{l}Q_{\text {def }} \\
\left(10^{6} \mathrm{~m}^{3} \text { year }^{-1}\right)\end{array}$ \\
\hline Measured & $1968-1998$ & 42 \\
HBV with measured & $1968-1998$ & 73 \\
precipitation & \\
HBV control run RCM & $1960-1990$ & 74 \\
KNMI & & \\
HBV scenario run RCM & $2070-2100$ & 292 \\
KNMI & & \\
\end{tabular}




\section{Discussion}

In comparison to most other river basins around the world, long and relatively reliable precipitation and discharge records are available for the Meuse. The hydrological processes in the Meuse basin are also relatively well known and have been simulated by numerous research groups. Nonetheless, there remain a number of restrictions in terms of the quality and availability of both (historical) data and hydrological models, which hamper an accurate hydrological simulation of critical low-flows in the Meuse.

Since a few years the rates of water abstraction to the canals between Liège and Borgharen have been monitored. Eventually this will result in a more reliable low-flow record for the 'undivided Meuse.' The model could also be improved by including humaninduced impacts, such as the regulation of weirs and the operation of reservoirs, in the hydrological simulation. However, this is difficult to achieve as the data required to include these impacts are spread over many different organisations in various countries. Despite the fact that rainfall-runoff models have a long history in hydrological science, their application specifically to low-flows has been relatively limited to date (Smakhtin 2001). This paper illustrates that a hydrological model should be validated specifically against low-flow indices. In this case it was found that a model with a generally good performance did not accurately simulate critical low-flows of the Meuse. A reliable estimation of groundwater storage, reservoirs and base flow requires an accurate and physically consistent simulation of all the interactions between the different parts of the hydrological cycle, especially in drought conditions (Dassargues et al. 1999). Good examples of the application of such models do exist for small catchments (e.g., Brouyère et al. 2004). The development of a physically based model that accounts for the heterogeneity of the sub-surface in a large international river basin, such as the Meuse, still requires considerable effort.

The results generated by the RCMs are strongly dependent on the lateral forcing of the GCMs by which they are driven (see e.g., the difference between the HadAM3H and ECHAM4/OPYC runs in Fig. 4). The estimation of the likelihood of dry summers preceded by anomalously dry winters therefore relies on a proper representation of the inter-annual variability of seasonal precipitation by these GCMs. The large difference in mean precipitation seasonality from the two GCM-simulations displayed in Fig. 4 points to the necessity to estimate the overall uncertainty in these modelled climate change signals. This can be addressed by constructing multi-model and multi-year ensembles of GCM-scenario runs, which is currently a high priority effort. Van Ulden and Van Oldenborgh (2005) analysed the skill and climate change signal of a wider range of GCM simulations used to make climate projections for the forthcoming fourth IPCC assessment. Their study highlights the importance of considering climate variability inherited from the large scale responses of GCMs.

Even using a single GCM, different RCMs are shown to generate different mean seasonal precipitation and evaporation patterns. In particular, summertime evaporation and runoff rates are shown to be sensitive to the specific RCM model formulation, as was demonstrated by Van den Hurk et al. (2005) for the Rhine basin. On a continental scale, land-atmosphere feedback processes may induce large differences in the regional hydrological cycle, which generates large inter-model differences in the summer precipitation regime, even for RCMs driven by common boundary conditions. It is as yet unclear how specific formulations in RCMs affect the correlation between winter and summer precipitation. In the brief analysis in the present study, no clear change in the interseasonal precipitation correlation was found (see Table 4). 
The observed and simulated (RCM) precipitation records show no significant correlation between the summer precipitation volume and the precipitation volume in the preceding winter (see Tables 3 and 4). This suggests that the occurrence of succeeding dry winters and dry summers is probably coincidental. Since 1976 there have been relatively few years with large discharge deficit volumes in the Meuse (see Fig. 8). However, there have been dry winters (e.g., 1995/1996) and dry summers (1989, 1990, 1991, and 2003) which did not coincide with each other (Fig. 6). Navigation on the Meuse and the use of the river for water supply in Belgium and The Netherlands has considerably increased during the last few decades. Hence the potential economic damage of low-flows is likely to increase independent of climate change.

\section{Conclusions}

The Meuse river has a pronounced rainfall-evaporation regime which generally produces lowflows during summer and high-flows during winter. The RCM simulations suggest a future with wetter winters and drier summers. This change will enhance the seasonality in the discharge regime of the river Meuse. The decrease of summer discharge does not necessarily mean that critical summer low-flows will become more severe and frequent. During dry spells, the discharge in the Meuse is largely derived from water releases from groundwater storage. The aquifers supplying this water are mostly recharged during the winter season. The increase of winter precipitation will therefore reduce the occurrence of low-flows to a certain extent. For the river Meuse, a wealth of hydrological data and modelling experience is available. Nevertheless, this paper illustrates that additional hydrological research is required regarding the simulation of critical low-flows in the Meuse basin.

Acknowledgements Part of the work was carried out within the framework of the Dutch National Research Programme on Global Air Pollution and Climate Change (NRP). The PRUDENCE consortium (see http:// prudence.dmi.dk) is acknowledged for making available the RCM-simulation results. We thank Martijn Booij and Robert Leander for sharing the HBV schematisation of the Meuse. Robert Leander also assisted with the HBV simulation for the RCM run. Finally we thank Philip Ward, Martijn Booij, Adri Buishand, and three anonymous reviewers for their valuable comments.

\section{References}

Ashagrie AG, de Laat PJM, de Wit MJM, Tu M, Uhlenbrook S (2006) Detecting the influence of land use changes on floods in the Meuse river basin - the predictive power of a ninety-year rainfall-runoff relation. Hydrol Earth Syst Sci Discuss 3:1-31

Bergström S, Forsman A (1973) Development of a conceptual deterministic rainfall-runoff model. Nord Hydrol 4:147-170

Booij MJ (2002) Appropriate modeling of climate change impacts on river flooding. PhD thesis, University of Twente, Enschede, The Netherlands (ISBN: 90-365-1711-7)

Booij MJ (2005) Impact of climate change on river flooding assessed with different spatial model resolutions. J Hydrol 303:176-198 (doi http://dx.doi.org/10.1016/j.hydrol.2004.07.013)

Bos H (1993) Verloop daggemiddelde afvoer Borgharen, periode 1911-1991. In: RIZA report 92.112x. RIZA, Lelystad, The Netherlands

Brouyère S, Carabin G, Dassargues A (2004) Climate change impacts on groundwater resources : modelled deficits in a chalky aquifer, Geer basin, Belgium. Hydrogeol J 12(2):123-134 (doi http://doi.dx.org/ 10.1007/s10040-003-0293-1)

Bultot F, Dupriez GL (1976) Conceptual hydrological model for an average-sized catchment area. J Hydrol 29:251-292

Christensen JH, Carter T, Giorgi F (2002) PRUDENCE employs new methods to assess European climate change. EOS 82:147 (see also http://prudence.dmi.dk) 
Dassargues A, Maréchal JC, Carabin G, Sels O (1999) On the necessity to use three-dimensional groundwater models for describing impact of drought conditions on streamflow regimes. In: Hydrological extremes: understanding, predicting, mitigating. In: Proc. IUGG 99 Symp. IAHS publication 255, $165-170$

Demarée G, Derasse S, Gellens D (1994) Hoogwaterstanden en wateroverlast van de Belgische Maas te Visé. Deelrapport in opdracht van het WL voor de Tweede Commissie Boertien. Royal Meteorological Institute of Belgium (RMI), Bruxelles, Belgium

De Roo APJ (2000) Physically based river basin modelling within a GIS: the LISFLOOD model. Hydrol Process 14:1981-1992

Déqué M, Jones RG, Wild M, Giorgi F, Christensen JH, Hassell DC, Vidale PL, Rockel B, Jacob D, Kjellström E, de Castro M, Kucharski F, van den Hurk B (2005) Global high resolution versus limited area model scenarios over Europe: results from the PRUDENCE project. Clim Dyn 25:653-670 (doi: http://doi.dx.org/10.1007/s00382-005-0052-1)

De Wit MJM, Warmerdam PMM,Torfs PJJF, Uijlenhoet R, Roulin E, Cheymol A, van Deursen W, van Walsum P, Ververs M, Kwadijk J, Buiteveld H (2001) Effect of climate change on the hydrology of the river Meuse. In: NRP report 410200 090. Dutch National Research Programme on Global Air Pollution and Climate Change. NRP, De Bilt

Gellens D, Roulin E (1998) Streamflow response of Belgian catchments to IPCC climate change scenarios. J Hydrol 210:242-258

Grabs W, Daamen K, Gellens D, Kwadijk J, Lang H, Middelkoop H, Parmet B, Stadler B, Schulla J, Wilke K (1997) Impact of climate change on hydrological regimes and water resources management in the Rhine basin. In: CHR report no. I-16. International Commission for the Hydrology of the Rhine Basin.

Hisdal H, Stahl K, Tallaksen LM, Demuth S (2001) Have streamflow droughts in Europe become more severe or frequent? Int J Climatol 21:317-333

IPCC (2001) Summary for Policymakers. A report of Working Group I of the Intergovernmental Panel on climate Change. http://www.ipcc.ch/

Jacob D, Bärring L, Christensen OB, Christensen JH, de Castro M, Déqué M, Giorgi F, Hagemann S, Hirschi M, Jones R, Kjellström E, Lenderink G, Rockel B, Sánchez Sánchez E, Schär C, Seneviratne SI, Somot S, van Ulden A, van den Hurk B (2007) An inter-comparison of regional climate models for Europe: design of the experiments and model performance. Clim Change, doi:10.1007/s10584-006-9213-4

Klein Tank AMG, Wijngaard JB, Können GP, et al (2002) Daily dataset of 20th-century surface air temperature and precipitation series for the European climate assessment. Int J Climatol 22:1441-1453

Kleinn J, Frei C, Gurtz J, Lüthi D, Vidale L, Schär C (2005) Hydrological simulations in the Rhine basin driven by a regional climate model. J Geophys Res 110, D04102 (doi: http://doi.dx.org/10.1029/2004JD005143)

Leander R, Buishand TA, Aalders P, De Wit MJM (2005) Estimation of extreme floods of the river Meuse using a stochastic weather generator and a rainfall-runoff model. Hydrol Sci J 50(6):1089-1103

Lindström G, Johansson B, Persson M, Gardelin M, Bergström S (1997) Development and test of the distributed HBV-96 hydrological model. J Hydrol 201:272-288

Middelkoop H, Daamen K, Gellens D, Grabs W, Kwadijk J, Lang H, Parmet B, Schädler B, Schulla J, Wilke $\mathrm{K}$ (2001) Impact of climate change on hydrological regimes and water resources management in the Rhine basin. Clim Change 49:105-128

Nash JE, Sutcliffe JV (1970) River flow forecasting through conceptual models. Part I. A discussion on principles. J Hydrol 10:282-290

Parry ML (ed) (2000) Assessment of potential effects and adaptations for climate change in Europe: the Europe ACACIA project. Jackson Environment Institute, University of East Anglia, Norwich, UK, p 320

Pilling C, Jones JAA (1999) High resolution climate change scenarios: implications for British runoff. Hydrol Process 13:2877-2895

Raïsänen J, Hansson U, Ullerstig A, Döscher R, Graham LP, Jones C, Meier HEM, Samuelsson P, Willén (2004) European climate in the late twenty-first century: regional simulations with two driving global models and two forcing scenarios. Clim Dyn 22:13-31

Roulin E, Vannitsem S (2005) Skill of medium-range hydrological ensemble predictions. J Hydrometeorol 6:729-744

Schär C, Vidale PL, Lüthi D, Frei C, Häberli C, Liniger MA, Appenzeller C (2004) The role of increasing temperature variability in European summer heatwaves. Nature 427:332-336

Sefton CEM, Boorman DB (1996) A regional investigation of climate change impacts on UK streamflows. J Hydrol 195:26-44

Seneviratne SI, Pal JS, Eltahir EAB, Schär C (2002) Summer dryness in a warmer climate: a process study with a regional climate model. Clim Dyn 20:69-85

Shabalova MV, van Deursen WPA, Buishand TA (2003) Assessing future discharge of the river Rhine using regional climate model integrations and a hydrological model. Clim Res 23:233-246 
Smakhtin VU (2001) Low flow hydrology: a review. J Hydrol 240:147-186

Van den Hurk B, Hirschi M, Schär C, Lenderink G, van Meijgaard E, van Ulden A, Rockel B, Hagemann S, Graham P, Kjellström E, Jones R (2005) Soil control on runoff response to climate change in regional climate model simulations. J Climate 18:3536-3551

Van Deursen W (2004) Calibration HBV model Meuse. In: Report to Rijkswaterstaat RIZA. Carthago Consultancy, Rotterdam (in Dutch)

Van Ulden AP, van Oldenborgh GJ (2005) Large-scale atmospheric circulation biases and changes in global climate model simulations and their importance for regional climate scenarios: a case study for West-Central Europe. Atmos Chem Phys Discuss 5:7415-7455 (doi: http://doi.dx.org/1680-7375/ $\operatorname{acpd} / 2005-5-7415)$ 